\title{
USTAVENÍ PARLAMENTU PŘI VYHLÁŠENÍ SAMOSTATNÉHO ČESKOSLOVENSKA A POLSKA: DVĚ RŮZNÉ CESTY S TÝMŽ CÍLEM*
}

\author{
JAN KUDRNA
}

\begin{abstract}
Establishing of the parliament during the process of declaring independence of Czechoslovakia and Poland: Two different ways with the same goal

This article compares the way, how the first parliaments were established in newly declared Czechoslovakia and Poland in 1918. The Czechoslovakian political representation decided for indirect way of establishing the parliament, which was even entitled to adopt the final constitution for the new state. On the other Polish politicians decided to establish the first parliament through the general elections. Both ways were different from the point of view of legitimacy. If we understand the legitimacy derived directly from the people as the superior form, then the Polish way was formally better. On the other hand there are also different sources of legitimacy, which are acceptable in the democratic states The lack of direct legitimacy could be overcome by time. The status quo or e.g. the constitution adopted by the indirectly established parliament may be understood as accepted by the people, if it is not changed later by the parliament elected directly in general elections. That was the Czechoslovak situation. Poland, which decided in favour of direct elections from the very start point, faced huge complications and was not able to provide the elections at the entire territory, as the new state was forces to conquer it firstly in many areas, which demanded in the moment of its proclamation. The Czechoslovak and Polish solution was thus different, but the result was very similar. Nonetheless, later in crucial moments of their histories both states tended to copy their first decision. Thus there could be seen some differences in their attitudes and political traditions.
\end{abstract}

Keywords: Czechoslovakia; Poland; constitution; elections; parliament; legitimacy; 1918; 1992

Klíčová slova: Československo; Polsko; ústava; volby; parlament; legitimita; 1918; 1992

DOI: $10.14712 / 23366478.2018 .23$

\section{I. ÚVODEM}

Vyhlášení nového státu s sebou nese celou řadu praktických problémů, které ve fungujících státech přes složitost každodenního provozu není nutno řešit. Na podzim roku 1918 bylo v Evropě vyhlášeno velké množství nových států, což dává

\footnotetext{
* Tento článek byl vypracován v rámci programu PROGRES Q04. Autor je odborným asistentem na katedře ústavního práva Právnické fakulty Univerzity Karlovy.
} 
př́ležitost k porovnání, jak jejich zakladatelé řešili některé základní problémy, které byly společné všem. Mezi ně patří ustavení parlamentu jako orgánu reprezentujícího obyvatelstvo nového státu.

Má-li se jednat o stát demokratický, počítající se suverenitou lidu, je nutno vyřešit složitou otázku, jak dosáhnout reprezentativnosti při zachování dostatečné akceschopnosti. Nový stát je zpravidla třeba vybojovat a udržet, a $v$ jeho počátcích je nutno řešit mnoho akutních problémů, přičemž všeobecné volby často nelze zorganizovat anebo to není možné v dostatečně krátké době.

V této věci se nabízí srovnání, jakým způsobem bylo postupováno v Československu a v Polsku. Oba státy vznikly v podstatě ve stejném období a za velmi podobných okolností, jedná se o státy sousední. Politická reprezentace každého z nich zvolila jiný způsob ustavení prvního parlamentu. $\mathrm{V}$ tomto př́padě můžeme říci, že alternativa ke zvolenému řešení existovala a můžeme také sledovat, jestli každé ze zvolených řešení vedlo nakonec $\mathrm{k}$ odlišnému výsledku.

\section{USTAVENÍ PRVNÍHO ČESKOSLOVENSKÉHO PARLAMENTU}

Při rozboru okolností, za kterých došlo k ustavení prvního československého zákonodárného sboru, nelze zkoumání celého tohoto procesu započít v momentu, kdy již byl parlament ustaven. Jeho konstituování bylo ve své podstatě vyvrcholením širšího a komplexnějšího vývoje probíhajícího již po delší dobu, a majícího své kořeny hlouběji v období právě končící světové války. $\mathrm{V}$ této době se rozhodovalo o událostech a činech, které byly na podzim roku 1918 uskutečněny.

Česká politická reprezentace byla za světové války rozdělena na dvě skupiny. První z nich byla tvořena představiteli českého národa vyvíjejícími svou činnost uvnitř domácího prostředí, zatímco druhá byla představována skupinou těch, kteří v prvním či druhém roce války odešli do zahraničí, aby zájmy české věci prosazovali u Dohodových mocností. Aktéři českého domácího i zahraničního odboje si byli vědomi, že úspěch každého převratu nespočívá pouze $\mathrm{v}$ převzetí moci, ale především $\mathrm{v}$ jejím následném udržení. Proto jsou již v průběhu roku 1918 prováděny nezbytné př́pravné práce nad základním rámcem budoucího právního rádu nového státu. Tato práce byla přirozeně dílem první skupiny, dominantní silou zde byla tajná organizace Maffie.

$Z$ těchto důvodů vznikly předlohy dvou základních zákonů, které měly upravit v nezbytné míře nově vzniklé poměry. Byl jím zákon politický a zákon hospodářský. Pro samotné institucionální uspořádání státu byla rozhodující řešení naznačená v zákoně politickém. Práce na obou předlohách začala v dubnu 1918. Práce na zákonu politickém vedl dr. Ferdinand Pantůček, prezident senátu Nejvyššího správního soudu ve Vídni, zákon hospodářský vznikl pod vedením dr. Jaroslava Preisse, ředitele Živnobanky. Návrhy zákonů byly $\mathrm{k}$ dispozici v konečné podobě na počátku záríí $1918 .{ }^{1}$

SOUKUP, F.: 28. řijen 1918. II. dil. Praha: Orbis, 1928, s. 836. 
Návrh zákona politického 2 je poměrně rozsáhlou předlohou, která se blíží spíše prozatímní ústavě, než recepční normě, která na jeho základě byla později vypracována. Uveden je preambulí a rozčleněn je na 33 základních článků. Návrh zákona věnuje značnou pozornost způsobu, jakým národ vykonává svou státní moc. Svrchovanost národa měla být vykonávána prostřednictvím zákonodárného sboru, který bude svolán na základě ústavy. Do té doby měl být národ zastupován Národním shromážděním, které mělo podle čl. 4 návrhu politického zákona vzniknout rozšiřením Národního výboru. Již v tomto návrhu budoucího politického uspořádání státu bylo počítáno s tím, že po určité období bude zákonodárná moc vykonávána nevoleným sborem. Významné je, že toto klíčové rozhodnutí bylo učiněno ještě před ř́ijnovým převratem.

Stejné je to ve věci rozšíření Národního výboru a jeho přetvoření v Národní shromáždění. Zde návrh zákona politického odkazuje na klíč, podle něhož bude zachován stávající poměr politických sil. Konečný počet členů Národního shromáždění nebyl stanoven, tato otázka byla ponechána otevřená další dohodě politických stran. Bylo však stanoveno, že každá ze stran zvolí své vlastní zástupce do Národního shromáždění sama.

Celá řada klíčových rozhodnutí realizovaných po vyhlášení samostatného československého státu byla učiněna $\mathrm{v}$ průběhu dubna až záŕí 1918 při pracích na obou rámcových normách. Pro ustavení parlamentu byly zásadní prvky odložení voleb a výběru poslanců Národního shromáždění politickými stranami ze svého středu. Obě tato řešení formovala dvacet meziválečných let nahlížení na parlament, mandát jeho členů a jejich vztah k politickým stranám, které je nominovaly.

Prvým zákonodárným orgánem samostatného československého státu se stal Národní výbor. ${ }^{3}$ Stalo se tak zákonem č. 11/1918 Sb. z. a n., kterým bylo současně vyhlášeno samostatné Československo. Osnova tohoto zákona byla připravena A. Rašínem v noci z 27. na 28. ř́jen tak, aby byla $\mathrm{k}$ dispozici pro prŕpad nutnosti jednat a bezodkladně vyhlásit samostatnost. Národním výborem byla projednána v průběhu dne a vyhlášena byla o šesté hodině večerní.

Jak je patrné z výše uvedeného, práce na zákoně nezačaly teprve v posledních dnech před převratem. Naopak při jeho stylizaci dr. Rašín využil již připravenou předlohu základního zákona politického, vypracovanou zvláštní komisí Maffie pod vedením dr. Pantůčka. Základní prvky jeho koncepce byly z připraveného návrhu přejaty, jednalo se ale pouze o myšlenkovou a koncepční inspiraci než o přejímání celých částí textu.

Národní výbor vykonával svou činnost jako orgán držící ve svých rukou veškerou státní moc v období od 28. října do 14. listopadu. Mezi jeho pravomoci patřil výkon moci zákonodárné, stejně jako moci výkonné. Velkým úkolem Národního výboru bylo ustavení Národního shromáždění, které by od něj převzalo jeho pravomoci v oblasti moci zákonodárné a mohlo by přijmout ústavu pro nový stát. Již víme, že rozhodnutí

2 Jeho plný text je uveden in: HODÁČ, F.: Doklady o prŕípravách k politickému a hospodářskému převratu. Obzor národohospodářský. Praha: J. Otto, spol. s r. o., 1926, ročník XXXI., s. 8 a násl. Dostupný také online: http://www.bibliothecaeconomica.cz/library/file/download.aspx?ID_File=912 [cit. 26. 1. 2018].

3 Na tomto místě nebudu uvádět podrobné historické okolnosti ustavení Národního výboru a vyhlášení nezávislého Československa, protože jsou čtenáři bud' známy anebo k tématu existuje rozsáhlá literatura. Pozornost soustředím na klíčové právní aspekty jeho transformace v Národní shromáždění. 
o způsobu řešení bylo učiněno dříve. Národní výbor se této záležitosti věnoval od 5 . listopadu 1918. To souviselo mj. s tím, že toho dne se vrátila oficiální delegace domácí reprezentace ze své cesty do Ženevy, kde byla také tato otázka projednána s představiteli zahraničního odboje. Na této ženevské schůzce bylo zjištěno, že Dohodové velmoci nemají žádné požadavky týkající se státní formy nového státu, ale že Národní rada ve svém prohlášení ze dne 18. ř́ijna deklarovala, že stát bude demokratickou republikou. V tomto směru nic nebránilo dříve zvolenému způsobu ustavení prvního československého parlamentu cestou delegace, a nikoliv cestou všeobecných voleb. O tři dny později předsednictvo Národního výboru oznámilo jeho ústavněprávní sekci potřebu př́pravy základního zákonného rámce, $\mathrm{v}$ jehož mezích by bylo možné konstituovat zákonodárný a ústavodárný sbor, jmenovat vládu a zvolit prezidenta. Práce na požadovaných předlohách byly dokončeny dne 13. listopadu 1918, kdy byla formou zákona Národního výboru ${ }^{4}$ vyhlášena prozatímní ústava. ${ }^{5}$ Následujícího dne se na své ustavující schůzi sešlo Národní shromáždění, které získalo přídomek „,revoluční“.

Na cestě k tomuto výsledku bylo nutno vyřešit problém, jakým mechanismem má být zákonodárný sbor ustaven. Jak jsem již uvedl, zásadní rozhodnutí bylo učiněno před říjnovým převratem a bylo směřováno pragmatickým směrem.

Volby by nebylo možné provést v horizontu několika dnů ani týdnů, ale jejich příprava by si vyžádala pravděpodobně spíše měsíce. Zcela jistě by nebyly volbami všeobecnými, nebot' v německých oblastech by bud' nemohly být provedeny, nebo by byly bojkotovány. ${ }^{6}$ Situace na Slovensku byla obdobná a trvalo ještě více než půl roku, než byly ze Slovenska vytlačeny mad'arské vojenské jednotky a mohla zde být ustavena státní moc. Provedení voleb na Podkarpatské Rusi bránil nejenom fakt, že její území nebylo podřízeno československému státu, ale jak se ukázalo později, celková zaostalost tohoto území nedovolila uspořádat parlamentní volby dříve než v roce 1924.

Výsledky případných voleb by byly v lepším případě pouze částečné, ale nemohly by být posuzovány jako reprezentativní. S takovým zásadním omezením možností daných přechodným charakterem panujících poměrů se museli vypořádat členové ústavní sekce Národního výboru při rozhodování o způsobu svolání Národního shromáždění.

V těchto úvahách hrála svou roli, byt' pravděpodobně nikoli hlavní, ale přesto nezanedbatelnou, možnost pokračovat v politickém rozhodování za stávajícího poměru sil,

4 Protože prozatímní ústava upravovala také otázku státního zřízení československého státu, došlo jejím schválením v Národním výboru k porušení ustanovení čl. II. zákona č. 11/1918 Sb. z. a n., který tuto pravomoc svěřoval Národnímu shromáždění.

5 Jejímu vydání předcházely dva zákony, které ji doplňovaly. Prvním z nich byl zákon č. 35/1918 Sb. z. a n. o osobní nedotknutelnosti členů Národního shromáždění, a zákon č. 36/1918 Sb. z. a n. o jednacím řádu Národního shromáždění. Osnovu prvého z nich připravil advokát V. Bouček, osnovu druhého advokát L. Winter.

6 Tomuto předpokladu odpovídala nejenom německá činnost, která vyvrcholila vyhlášením čtyř provincií v pohraničních oblastech, usilujících o připojení k německému Rakousku, ale také výsledek schůzky předsednictva Národního výboru s německými představiteli o možnosti jejich pozvání k činnosti v Národním výboru. Tuto nabídku během jednání uspořádaného dne 31. ř́ína v Praze zemský hejtman župy Deutschböhmen dr. Lodgman kategoricky odmítl a vyjádřil přesvědčení, že otázka prŕslušnosti českých Němců bude vyřešena mírovou konferencí. Do té doby, zdůraznil, mají čeští Němci svůj stát stejně, jako Češi. Viz PEROUTKA, F. Budování státu. I. díl. Praha: Nakladatelství Lidové noviny, 1991, s. 119. 
který v zásadě všem politickým stranám vyhovoval. Zároveň panující situace umožňovala pokračovat $\mathrm{v}$ revolučním pořádání politických a státních poměrů.

Zvolena tedy byla cesta rozšíření Národního výboru v Národní shromáždění prostřednictvím delegace zástupců politických stran. Vyjádřen byl tento princip v § 1 zákona č. 37/1918 Sb. z. a n. o prozatímní ústavě. Prozatímní ústava, přijatá ještě Národním výborem dne 13. listopadu 1918, stanovila, že Národní výbor se rozšíŕí na 256 členů způsobem a podle takového klíče, podle jakého Národní výbor vznikl. Ústava pro nový sbor zvolila název Národní shromáždění.

Kromě skladby zákonodárného sboru bylo nezbytné určit také počet jeho členů. Tvůrce osnovy prozatímní ústavy, dr. Meissner, navrhoval pro Národní shromáždění 250 poslanců. Tomuto číslu odpovídalo přibližně zešesteronásobení ${ }^{7}$ počtu členů Národního výboru. Přesto však nebylo možno dosáhnout tohoto zaokrouhleného čísla, aniž by byla porušena rovnováha politických sil.

Proto byl „Švehlův klíč“ použit pouze jako základní východisko a konečný počet poslanců byl určen na základě dalších politických dohod. V novém Národním shromáždění měly najít své zastoupení i některé menší strany nefigurující v Národním výboru, a především měla být zajištěna místa také pro slovenskou reprezentaci. $Z$ menších stran a skupin se jednalo naprŕiklad o stranu živnostenskou a skupinu anarchistickou. Slovenští reprezentanti získali čtyřicet mandátů. Dalších deset členů Národního shromáždění bylo kooptováno z kandidátů stojících mimo politické strany. ${ }^{8}$

Během politických jednání tak byl počet poslanců budoucího Národního shromáždění stanoven na $256 .{ }^{9}$ Toto číslo nebylo výsledkem prvotního politického rozhodnutí, ale bylo určeno až v průběhu podrobných politických vyjednávání. Stalo se tak vyjádřením praktického politického kompromisu.

7 Přinejmenším takové vysvětlení způsobu dosažení konečné cifry stanovící počet poslanců podává F. Peroutka ve své výše citované knize. PEROUTKA, F. Budování státu. I. díl. Praha: Nakladatelství Lidové noviny, 1991, s. 166.

Jeho propočet však neodpovídá skutečnosti, nebot' se snaží nalézt vztah mezi počtem členů Národního výboru a konečným počtem poslanců Národního shromáždění. K nalezení skutečné relace mezi oběma ciframi je třeba odečíst nejprve počet mandátů, které získala slovenská reprezentace, a dále počet deseti kooptovaných nestraníků z řad význačných osobností, a počet mandátů přidělených menším stranám a společenským skupinám. Tímto způsobem dospějeme k číslu 200, které potom odpovídá spíše pětinásobku počtu členů Národního výboru. Tomuto koeficientu odpovídá i počet poslanců, které získaly jednotlivé, zejména velké strany.

Původní Národní výbor byl tedy rozšířen přibližně na pětinásobek své velikosti. Takto stanovené mandáty získaly hlavní české politické strany v zásadě podle „Švehlova klíče“. Další mandáty byly přiděleny již mimo tento systém.

8 Popsaný mechanismus nelze dovodit z žádné zákonné normy. Prozatímní ústava jako základní zákon státu tak poněkud paradoxně odkazuje jako na další pramen na politickou dohodu. Dikce $\S 1$ prozatímní ústavy je navíc poněkud nepřesná, nebot' odkazuje de facto pouze na „Švehlův klíč“, ale nikoli na jeho další modifikace, díky nimž byly mandáty přiděleny také slovenské politické reprezentaci, a část mandátů byla určena pro kooptace významných nepolitických osobností. Pokud by mělo být ustanovení $§ 1$ bezvýhradně naplněno, nebylo by možné poslední dvě skupiny mandátů naplnit, respektive musely by být naplněny jiným způsobem. Politické strany by musely například za své kandidáty přijmout slovenské politiky. Ti by se tak nestali reprezentanty svého národa, ale především českých politických stran, které by je delegovaly.

9 Plného počtu 256 poslanců však nebylo až do první novelizace prozatímní ústavy dosaženo. Fakticky mělo Národní shromáždění pouze 254 členů. Viz Národní shromáždění republiky československé v prvém desetiletí. Praha: Předsednictvo Poslanecké sněmovny a předsednictvo Senátu, 1928, s. 17. 
V prozatímní ústavou stanoveném počtu nezasedalo Národní shromáždění dlouho. I když byla zvolená metoda rozdělení mandátů mezi politické strany všeobecně přijata, byla stále pouze kompromisem, který nemohl vyhovět všem.

Největší nespokojenost však nezaznívala z řad některé politické strany, ale vyjadřovali jí členové slovenské reprezentace. Při rozdělování poslaneckých mandátů nemohl být v př́padě Slovenska použit „Švehlův klíč“, nebot’ na Slovensku nefungoval natolik rozvinutý systém politických stran, který by bylo možno využít, jako tomu bylo v českých zemích. Tato skutečnost spolu s hrozbou tvrdého postihu jakékoliv protimad'arské politiky způsobila, že v den převratu byl jediným Slovákem v Národním výboru dr. V. Šrobár.

Pokud by došlo pouze k důsledné aplikaci „Švehlova klíče“, získalo by Slovensko pro své zástupce v Národním shromáždění pět, nejvýše šest mandátů. $Z$ toho důvodu došlo nejprve $\mathrm{k}$ poměrnému rozšíření výboru, při němž byly přiděleny mandáty pouze politickým stranám z českých zemí, a teprve potom byla zvláštní skupina mandátů určena výhradně pro slovenské poslance. Tímto způsobem Slovensko získalo poslanecká místa pro 24 svých reprezentantů.

Personálně byly přidělovány mandáty podle rozhodnutí těch slovenských politiků, kteří udržovali úzké kontakty s Národním výborem. Největší vliv na výběr slovenských poslanců měl v praxi V. Šrobár.

Řada mandátů určených pro slovenské zástupce však byla přidělena Čechům, zejména takovým, kteří byli známi jako stoupenci česko-slovenské jednoty a vzájemnosti a aktivně se zasazovali o slovenskou věc. Některé z dalších míst byly přiděleny také významným českým osobnostem, které nebyly členy žádné strany, nezískaly jeden z deseti mandátů určených pro kooptace, ale přesto svým významem do Národního shromáždění patřily. ${ }^{10}$

Jestliže došlo k relativně spravedlivému rozdělení mandátů mezi českými politickými stranami, v prrípadě poslaneckých míst určených pro zástupce Slovenska tomu tak nebylo. Proto již 20. listopadu, tedy týden po ustavení Revolučního národního shromáždění, podala skupina 29 poslanců návrh ${ }^{11}$ na změnu prozatímní ústavy, která by vedla k rozšíření počtu členů Národního shromáždění z 256 na 270 s tím, že dodatečných 14 mandátů by bylo rozděleno mezi Slováky.

Navrhovatelé argumentovali především nedostatečným zastoupením slovenského národa z hlediska proporcionality. Jak uvádějí, české země získaly 216 poslanců při přibližně deseti miliónech obyvatel, a Slovensko s přibližně třemi milióny obyvatel pouze 40 mandátů, ačkoli podle zásad poměrnosti by mělo mít nárok dokonce na 64 poslanců, tedy o 24 více, než jim bylo přiznáno prozatímní ústavou. ${ }^{12}$

10 Takto získali poslanecký mandát např. E. Beneš nebo A. Masaryková. Viz např. KREJČÍ, O.: Kniha o volbách. Praha: Victoria Publishing, 1994, s. 114.

11 Publikován byl jako o tisk Revolučního národního shromáždění č. 41.

$12 \mathrm{Na}$ tomto místě je třeba upozornit, že předkladatelé vycházeli při svých výpočtech z počtu veškerého obyvatelstva českých zemí a Slovenska. Uvedený poměr nebyl pouze poměrem mezi př́slušníky národa českého a slovenského, ale zahrnoval také př́slušníky dalších národností obývajících území historických zemí. V tomto smyslu poslanci Revolučního národního shromáždění reprezentovali nikoli pouze svou národnostní skupinu, ale v rámci probíhajících revolučních kroků celé př́slušné teritorium dané historické země. 
Za této situace upozorňovali slovenští poslanci, nemohly být zastoupeny rádně všechny důležitější společenské třídy a vrstvy slovenského národa. Situace se zejména dotýkala zemědělské a sociálnědemokratické strany.

Nízký počet slovenských poslanců nedovolil dále jejich adekvátní zastoupení a rádnou práci v parlamentních výborech, protože řada slovenských poslanců se musela podílet na práci tří až čtyř výborů. Jejich činnost byla o to obtížnější, že s ohledem na svou hmotnou závislost na dosavadním povolání se nemohli zúčastnit v plném počtu na práci shromáždění.

Proti slovenským poslancům se stavěla ještě jedna skutečnost, kterou navrhovatelé ve své zprávě neuváděli. Tou byla špatná dopravní situace způsobená nedostatkem komunikací mezi českými zeměmi a Slovenskem.

Ústavní výbor návrh projednal a doporučil jej ke schválení. Ve své zprávě ${ }^{13}$ zdůraznil především neodpovídající poměr mezi mandáty a počtem obyvatel ve srovnání českých zemí a Slovenska, poukázal na skutečnost, že řada slovenských poslanců pracuje na místech poradců ministra s plnou mocí pro Slovensko, a tato vytíženost jim často brání vykonávat řádně poslanecký mandát, a kromě toho upozornil navíc na špatné dopravní spojení mezi českými zeměmi a Slovenskem.

Podaný návrh byl plénem Národního shromáždění projednán na 35. schůzi dne 11. března. $\mathrm{V}$ rozpravě $\mathrm{k}$ návrhu nezazněly žádné další argumenty kromě těch, které byly uvedeny v samotném návrhu a zprávě ústavního výboru $\mathrm{k}$ němu. Poté byl návrh potřebnou ústavní většinou schválen a vyhlášen jako zákon č. 138/1919 Sb. z. a n. ${ }^{14}$

Nově zřízené mandáty byly přiděleny již většinou Slovákům. Tím došlo alespoň k částečnému vyrovnání nerovnoměrného rozdělení mandátů mezi české a slovenské poslance, i když, jak bylo uvedeno v samotném návrhu, k dosažení úplné formální proporcionality by bylo třeba zř́zení dalších více než deseti ${ }^{15}$ poslaneckých míst. Ke skutečnému vyrovnání by bylo třeba nově obsadit mandáty, které za Slováky zastávali čeští poslanci.

Reprezentativnost Národního shromáždění ve vztahu ke Slovákům nebyla omezena pouze slabším zastoupením, než jaké by jim správně náleželo, ale také výběrem osob, které mandáty získaly. Jednalo se především o stoupence československé jednoty, což bylo příznivé novému státu, ale tento výběr byl proveden uměle a neodpovídal zcela rozvrstvení slovenské společnosti a její politické reprezentace.

Jestliže české politické strany reprezentovaly poměrně věrně všechny významnější politické proudy existující v české společnosti, a svou politikou v zásadě naplňovaly představy českého národa o novém státě, slovenská politická reprezentace byla zalo-

13 Zpráva ústavního výboru k podanému návrhu byla publikována jako parlamentní tisk č. 568. Schválena byla dne 26. února 1919 .

$14 \mathrm{Z}$ legislativně-technického hlediska je znění zákona zajímavé tím, že změnilo pouze počet poslanců, kteří mají zasedat v Národním shromáždění. Ke způsobu jeho vzniku, případně rozdělení dodatečně zř́zených mandátů se zákon nevyjadřuje.

Ze samotného znění této novelizace prozatímní ústavy nelze dovodit, že nové mandáty mají být přiděleny pouze slovenským reprezentantům. Tento nedostatek má však i původní znění dotčeného § 1, který zvláštní část mandátů rezervovaných slovenským poslancům nezmiňuje.

15 Př́i poměru mezi počtem obyvatelstva $\mathrm{v}$ českých zemích a na Slovensku by mandáty měly být rozděleny v poměru přibližně $10: 4$ a slovenským poslancům by mělo připadnout přibližně $28,6 \%$ všech mandátů. Při celkovém počtu 256 poslaneckých míst mělo být celkem 73 mandátů rezervováno pro Slováky. 
žená metodou svého výběru daleko jednostranněji a některé politické skupiny zcela opomíjela.

Téměř bezprostředně po vyhlášení prozatímní ústavy a rozšǐření Národního výboru v Národní shromáždění se počaly ozývat hlasy kritizující způsob, jakým byly tyto politické a právní kroky provedeny. Národnímu výboru byla vytýkána především jeho nedostatečná reprezentativnost daná jeho národnostní uniformitou, ústavě, kterou vypracoval, potom oktrojový charakter. Hlasy zastánců takto kritického postoje byly posilovány ještě ustanovením $\S 4$ prozatímní ústavy, z něhož vyplývalo, že definitivní ústava bude vypracována ještě zákonodárným sborem vzniklým cestou delegace a nikoli všeobecnými volbami. Budoucí ústavní listina tak měla vzejít ještě z parlamentu vzniklého delegací, což mělo ovlivnit její charakter.

Jednotliví poslanci nevystupovali v pozici zástupců lidu, ale pouze delegátů politických stran, jimž byli politicky odpovědní. Vykonavatelem svrchovanosti a suverénem v revolučním období existence československého státu tedy nebyl lid, ale politické strany. Jimi připravená ústava potom byla schválena bez souhlasu lidu či jím legitimovaných zástupců, a tedy, jak namítali odpůrci zvoleného způsobu jejího schválení, byla lidu vnucena. ${ }^{16}$

Nelze zpochybnit, že tyto kritické námitky mají svou váhu. Současně je ale nutné vzít v úvahu také to, že československý stát, jeho orgány a jeho ústava vznikaly ve skutečně bouřlivých poměrech, kdy konečný výsledek těchto procesů byl nejistý. Přirozeně svou roli sehrál také politický pragmatismus představitelů českých politických stran. Nicméně $\mathrm{v}$ celé záležitosti nešlo o to samostatný stát pouze vyhlásit, ale také ustavit a udržet. V takové situaci je nutno uplatňovat odlišná hodnotící kritéria, než v časech stability.

Hodnocení prozatímní ústavy jako oktrojované je přehnané, protože je ústavou revoluční. V př́ípadě ústavní listiny z roku 1920 je nepochybně její vadou, nicméně otázkou je, zda vadou nezhojitelnou, že nebyla schválena zvoleným Národním shromážděním. Legitimita jak orgánů, tak předpisů, má různé možné zdroje. Jedním z nich je př́ímo či nepřímo vyjádřená vưle lidu. Dalším zdrojem legitimity je ale akceptace v čase. Z tohoto hlediska ústavní listina z roku 1920 obstála. Národnostní problémy zvětšované vnějšími vlivy, které stály za koncem 1. československé republiky, s ústavní listinou souvisely, ale ona ani způsob jejího schválení nebyly ani jejich příčinou, ani překážkou jejich řešení.

Závěrem můžeme shrnout, že volby v Československu měly být provedeny teprve v okamžiku, kdy bude možné zajistit nejen jejich řádný průběh, ale kdy se jich bude moci zúčastnit také veškeré obyvatelstvo státu, aby zvolený zákonodárný sbor byl skutečně reprezentativním orgánem.

16 Viz zejména VAVŘínEK, F.: Základy práva ústavního. Díl I. Praha: Všehrd, 1920, s. 85. F. Vavřínek výslovně upozorňuje, že ústavní listina přijatá v roce 1920 má opět povahu ústavy oktrojované, nebot' nebyla usnesena voleným sborem. Jeho námitky se týkají stejně prozatímní ústavy. Na problém nedostatku legitimity upozornil během schvalování prozatímní ústavy na poslední schůzi Národního výboru konané dne 13. listopadu 1918 také Karel Engliš, byt' daleko mírněji. Navrhl proto, aby zákonodárná moc nevoleného Národního shromáždění byla omezena pouze na záležitosti „pilné a neodkladné“. Jeho návrh však nebyl přijat. Stenozáznam z jednání dostupný online: http://www.psp.cz/eknih/1918nvc/sten$\operatorname{prot} / 19181113 / 19181113$ _03.htm [cit. 26. 1.2018]. 


\section{USTAVENÍ PRVNÍHO POLSKÉHO PARLAMENTU17}

Jiný způsob řešení rozporu mezi nutností efektivně jednat v zájmu zajištění základů státu a zájmem na legitimování činnosti státních orgánů vůlí lidu zvolilo sousední Polsko. Zde vydala Státní rada již dne 28. listopadu 1918 dva dekrety, na jejichž základě mohly být 26. ledna 1919 provedeny volby do Ústavodárného sněmu. Jednalo se o dekret č. 46 z roku 1918 o volebním zákoně do Ústavodárného sněmu ${ }^{18}$ a dekret č. 47 z roku 1918 o volbách do Ústavodárného sněmu. ${ }^{19}$

Obnovený polský stát tedy v rychlosti provedení voleb předstihl Československo. Tento př́klad je velmi cenný pro přiblížení toho, jaké výsledky by pravděpodobně přineslo provedení voleb v Československu před upevněním státní moci. Podobně jako v př́padě Československa, hranice Polska a jeho územní rozsah měly být s definitivní platností určeny až na mírové konferenci. Oproti Československu však byla územní situace Polska o to složitější, že neexistovala žádná historická hranice, kterou by jeho sousedi respektovali jako pevnou, a s výjimkou bývalého rakouského záboru vznikl polský stát odtržením z území nadále existujících sousedních států. Volby byly tedy provedeny za situace, kdy hranice státu byly značně pohyblivé a jeho území proměnlivé. Situace Polska tak byla v tomto směru podobná situaci panující v Československu. Naproti tomu bylo polské území národnostně daleko homogennější a před uzavřením rižského míru a připojení východních území tvořilo polské obyvatelstvo výraznou většinu všech obyvatel státu. Českoslovenští politikové se museli vyrovnat se situací, kdy český národ tvořil přibližně 50 \% všech obyvatel a ve spojení s národem slovenským bylo dosaženo většiny přibližně $65 \%$ všech obyvatel. ${ }^{20}$

Podle ustanovení dekretu č. 46/1918 byl pro volby do Ústavodárného sněmu zvolen systém poměrného zastoupení, kdy jeden poslanecký mandát připadal na 50 tisíc voličů. Respektovány byly zásady všeobecnosti, rovnosti a př́mosti voleb provedených tajným hlasováním. Území celého státu bylo rozděleno na 70 volebních obvodů, ve kterých bylo rozdělováno od 3 do 13 mandátů. Seznam všech volebních obvodů byl obsažen $\mathrm{v}$ př́loze č. 1 dekretu.

Do seznamu volebních obvodů však bylo zahrnuto nejenom území, které v době vyhlášení dekretu již spadalo pod svrchovanost polského státu, ale také ty oblasti, na které si nový stát činil nárok. Tento problém se dotýkal všech tř́ bývalých záborů. Od samého počátku bylo zřejmé, že volby nebudou moci být provedeny na všech územích, která volební zákon určil. Tím byl korigován původní záměr zákonodárce vyjadřující spiše národní aspirace než přihlédnutí $\mathrm{k}$ reálné situaci. Volby byly omezeny pouze na ta území, která státní moc skutečně ovládala.

Prvá úprava volebních obvodů byla ještě před uskutečněním voleb provedena již dekretem č. 47 z roku 1918. Podle jeho ustanovení měly být volby provedeny pouze ve

17 Základem této pasáže je část mého textu z př́spěvku „Ke způsobu ustavení zákonodárných orgánů při vzniku samostatného Československa a Polska“ in: KLÍMA, K. - JIRÁSEK, J.: Pocta Jánu Gronskému. Plzeň: Aleš Čeněk, 2008, která byla doplněna a přepracována.

18 Dz. U. $1918 \mathrm{nr} 18$ poz. 46.

19 Dz. U. 1918 nr 18 poz. 47.

20 Bližší údaje o národnostní skladbě československého státu viz např. Kol. autorů: Rozumět dějinám. Praha: Gallery, 2002, s. 56. 
46 volebních obvodech z původně stanovených 70 , a to z důvodu nemožnosti provedení voleb zejména na východních územích nárokovaných, ale nekontrolovaných Polskem $\mathrm{v}$ dané době.

Aby však území volebních obvodů č. 46-59 nebyla ve svolaném sněmu bez zastoupení, bylo stanoveno, že z nich budou do Sejmu povoláni bývalí polští poslanci, kteří zastupovali uvedené obvody v rakouské poslanecké sněmovně. Protože dva poslanecké mandáty ve Lvově byly z důvodu úmrtí volné, bylo v jejich př́padě stanoveno, že obsazeny budou $\mathrm{v}$ doplňovacích volbách provedených podle rakouského volebního zákona z roku 1907.

Obdobná situace nastala také v oblasti bývalého pruského záboru zahrnujícího obvody č. 60-70, pro které bylo stanoveno, že volby budou zorganizovány po dohodě s Poláky obývajícími tato území. Na základě dekretu č. 193 ze dne 8. února $1919^{21}$ byli jako zástupci pruského záboru do Ústavodárného sněmu povoláni ti bývalí polští poslanci, kteří dané území zastupovali v německém parlamentu. Zvláštním způsobem mělo být postupováno v př́ípadě oblasti Vilniusu (Wilna) a Poláků na Litvě a v Rusku.

Jak je patrné, již na samém počátku bylo zřejmé, že volby nebudou uskutečněny na celém území státu. Ve skutečnosti proběhly pouze v bývalé „Kongresovce“ (část záboru ruského) a západní Haliči (část záboru rakouského). To odpovídalo ustanovením dekretu č. 47/1918. Naproti tomu neproběhly volby např. v oblasti Těšínska, o které vedlo Polsko spor s Československem, ale ani v hospodářsky významné oblasti Poznaňska ležící v bývalém pruském záboru. Polskému státu se tak nepodařilo provést volby v dekrety zamýšleném rozsahu, ale pouze na územích, která podléhala jeho svrchovanosti.

S tím, jak byly do Polska začleňovány další oblasti, bylo nutné provádět doplňovací volby, které by zajistily jejich řádnou reprezentaci v Ústavodárném sněmu. Jedním ze zákonů, na jehož základě byly provedeny volby v oblasti Poznaňska, byl zákon č. 253 ze dne 5. dubna 1919.22 Doplňovací volby v další části bývalého pruského záboru byly provedeny na základě zákona č. 393 ze dne 1 . srpna $1919,{ }^{23}$ projednaném ve zrychleném procesu jako parlamentní tisk č. $882^{24}$ spolu se zprávou ústavní komise uveřejněnou jako tisk číslo $954 .{ }^{25}$ I tento zákon však počítal s tím, že do doby provedení doplňovacích voleb budou obvody, které přejdou pod polskou správu pouze částečně, i nadále zastupovány bývalými poslanci německého parlamentu.

Doplňovací volby však byly prováděny především v oblasti bývalého záboru pruského a západní části záboru rakouského (zde byly provedeny volby v polské části těšínského Slezska). Východních území se tato opatření v zásadě nedotýkala. Určitou výjimkou byl zákon č. 294 ze dne 10. května 1919, na jehož základě byly provedeny volby v již zmíněné oblasti Těšínska a také Bialstoku (Białegostoku).

V roce 1921, kdy již byly mírovými smlouvami pevně určeny hranice polského státu, bylo možné konstatovat ve věci provedených voleb následující. Řádné volby provedené v lednu 1919 na základě prozatímního volebního zákona obsaženého v dekretech

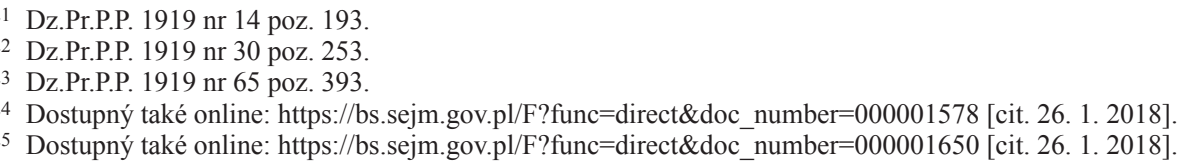


č. 46 a 47 z roku 1918 proběhly pouze na území bývalého Kongresového království a v západní Haliči. V oblasti pruského záboru byly provedeny doplňovací volby v průběhu roku 1919, po uzavření Versailleského míru také v roce $1920 \mathrm{v}$ oblasti tehdejšího polského Pomoří. Z východní Haliče byli povoláni bývalí polští poslanci zastupující toto území v rakouské poslanecké sněmovně a volby, a to ani doplňovací, s výše uvedenou výjimkou týkající se Lvova, zde provedeny nebyly. V oblasti Těšínska byly volby připraveny již v lednu 1919, ale po vojenském zákroku ze strany Československa zde provedeny být nemohly. Pouze v části tohoto území byly provedeny doplňovací volby dne 15. června 1919. Část poslanců za toto území byla později povolána na základě dohody politických stran, tedy cestou kooptace.

Naproti tomu na východních územích, která Polsku připadla rižským mírem, volby provedeny nebyly a tyto rozsáhlé oblasti, z velké části osídlené nepolským obyvatelstvem, své zastoupení v polském parlamentu neměly.

Definitivní volební zákony byly připraveny teprve $\mathrm{v}$ roce 1922 . Jednalo se o zákon č. 590 ze dne 28. července 1922 o volbách do Sejmu, ${ }^{26}$ a o zákon č. 591 z téhož dne o volbách do Senátu. ${ }^{27} \mathrm{Na}$ jejich základě byly volby do Sejmu provedeny dne 5 . listopadu a volby do Senátu dne 12. listopadu 1922. Tímto dnem byl teprve zvolen zákonodárný sbor na celém území Polska.

Na rozdíl od Československa se v Polsku podařilo uspořádat volby velmi rychle a státní orgány tak mohly získat, jak bylo alespoň deklarováno, legitimaci ke své činnosti prímo od lidu. Stalo se tak však přirozeně pouze na územích kontrolovaných polskou státní mocí. Vedle toho zůstává otázkou, nakolik měly provedené volby v důsledku četných omezení daných těžkou situací v počátku ustavování státu skutečně reálný obsah a nakolik byly pouze formálním aktem bez větší váhy. Zejména v počátečních obdobích poslanci Ústavodárného sněmu reprezentovali pouze menší část obyvatel Polska. I když se tento nedostatek podařilo $\mathrm{v}$ průběhu doby pomocí doplňovacích voleb částečně odstranit, zůstává skutečností, že až do konce volebního období své zástupce v parlamentu neměla východní území. Lze také pochybovat, zda doplňovací volby v jednotlivých obvodech proběhly za stejných podmínek, zvláště porovnáme-li je s volbami celostátními. Samotné zorganizování všeobecných voleb za situace, $v$ níž se nový polský stát na přelomu let 1918-1919 nacházel, nemohlo proběhnout tak, aby byly zcela bez problémů naplněny požadavky volebního zákona.

Všechny tyto skutečnost ostatně přiznává zpráva ústavní komise Ústavodárného sněmu k návrhům volebních zákonů do Sejmu a Senátu, vydaná jako parlamentní tisk č. 3444. ${ }^{28}$ Komise ve své zprávě konstatuje, že při předešlých volbách a následných doplňovacích volbách nemohlo dojít k objektivnímu zjištění, kolik hlasů připadalo na jeden mandát, a to zejména proto, že $\mathrm{v}$ letech 1919-1921 nebyly $\mathrm{k}$ dispozici údaje o přesném počtu obyvatel žijících na územích, která byla přičleněna k polskému státu. Sčíńní obyvatelstva bylo provedeno teprve $\mathrm{v}$ roce 1921 a jeho výsledky tak mohly být použity teprve při př́pravě definitivních volebních zákonů. Komise také udává, že na některých územích vůbec k volbám nedošlo.

26 Dz.U. 1922 nr 66 poz. 590.

27 Dz.U. 1922 nr 66 poz. 591.

28 Dostupný také online: https://bs.sejm.gov.pl/F?func=direct\&doc_number=000004148 [cit. 26. 1. 2018]. 


\section{ZÁVĚR}

Vzhledem k podobnosti situace $\mathrm{v}$ obou státech je možné odhadovat, že Československo by v př́padě, že by se rozhodlo ve prospěch rychlého provedení parlamentních voleb, prošlo podobným vývojem jako Polsko. Československá cesta, i když vhodnější by bylo s ohledem na složení politické reprezentace hovořit o české cestě, byla klidnější a př́mější než polské řešení. $Z$ praktického hlediska bylo dosaženo téhož. $Z$ hlediska teorie je takové řešení také odůvodnitelné, a to s odkazem na revoluční charakter konání.

V případě, že by se Národní výbor, př́ípadně prozatímní Národní shromáždění, rozhodl pro co nejrychlejší provedení voleb, podařilo by se mu je uskutečnit s největší pravděpodobností pouze na územích obývaných českým obyvatelstvem. V pohraničí a na Slovensku by potom musely být prováděny postupně doplňovací volby s tím, jak by tato území byla postupně podřizována československé státní moci. Jejich provádění by bylo navíc na Slovensku, ale zejména na Podkarpatské Rusi z důvodu chybějících informací o počtu obyvatelstva obtížné, jak se ostatně ukázalo později.

Českoslovenští politici také museli počítat s daleko silnějším postavením národnostních menšin a své kroky museli poměřovat také tímto hlediskem. Situace Polska byla $\mathrm{v}$ tomto směru jednodušší, alespoň do připojení východních území.

Značnou nevýhodou Polska naproti tomu bylo jeho původní rozdělení mezi tři sousední státy, v důsledku čehož neexistovala jednotná národní reprezentace, jak tomu bylo alespoň v př́ípadě českých zemí. Nově zvolený ústavodárný orgán, byt' nezastupující všechny obyvatele nového státu, byl prvním jednotným orgánem obnoveného státu. Jiná politická situace panující v českých zemích umožnila odložení voleb na pozdější dobu, což dalo čas $\mathrm{k}$ jejich řádné přípravě.

Mám za to, že obě cesty, československá či česká, i polská, jsou pro tehdejší situaci s hlediska státovědného či ústavněprávního akceptovatelné, pokud jde o způsob ustavování orgánů nového státu. Československý či český pragmatismus je možné do jisté míry kritizovat z hlediska způsobu př́ípravy definitivní ústavy. Její legitimita by byla silnější, kdyby byla připravena a schválena voleným parlamentem. Jak jsem ale uvedl již výše, legitimita nemá jediný zdroj v podobě vůle lidu, ale vychází také z akceptace $\mathrm{v}$ čase.

Platí ale také to, že jednou zvolený postup legitimuje či otevírá cestu takovému postupu v podobné situaci v budoucnu. Při prŕpravě ústavy v roce 1992 se zopakovala ve své podstatě situace $\mathrm{z}$ let $1918-1920$ a otevřely se podobné doktrinární i praktické otázky. ${ }^{29}$ Zajímavostí je, že v sousedním Polsku došlo po obnovení demokracie na konci

29 Za ústavně problematický považuje způsob přijetí Ústavy České republiky setrvale profesor Zdeněk Jičínský. Své argumenty uvádí zde: JIČİNSKY, Z.: K legitimitě parlamentu samostatné ČR. In: KYSELA, J. (ed.): Deset let Ústavy České republiky? Východiska, stav, perspektivy. Praha: Eurolex Bohemia, 2003, s. 72 a n. Obdobně také profesor Jiř́i Malenovský, který způsobu vzniku Ústavy České republiky vytýká demokratický deficit. Jeho argumenty viz zde: MALENOVSKÝ, J.: O legitimitě a výkladu české Ústavy na konci století existence moderního českého státu. Právník. 2013, roč. 152, č. 8, s. 748-750.

V širším pojetí se této otázce aktuálně věnuje Veronika Svoboda, viz její článek: SVOBODA, V.: Okolnosti a techniky vzniku a změn ústav se zvláštním zřetelem ke vzniku ústavy České republiky. Právník. 2018, roč. 156 , č. 1, s. $1-13$. 
80. let také do značné míry k zopakování situace z období obnovy samostatného státu $\mathrm{v}$ roce 1918. Polští političtí reprezentanti zvolili cestu př́ípravy nové ústavy v řádně a za účelem př́ípravy ústavy zvoleném parlamentu. V České republice byl zvolen mnohem pragmatičtější prístup.

I když je samozřejmě každá historická situace jedinečná, existují určité obecné podobnosti napříč časem a prostorem, a v tomto smyslu se zdá, že existují jisté rozdíly $\mathrm{v}$ př́stupu $\mathrm{k}$ řešení obdobných problémů $\mathrm{v}$ českých či československých a polských moderních dějinách. Pro Českou republiku je dosti typické, že se v klíčových momentech sahá $\mathrm{k}$ pragmatickým a praktickým řešením nepočítajících s participací lidu. To by ale již bylo téma na jinou práci.

JUDr. Jan Kudrna, Ph.D.

Právnická fakulta Univerzity Karlovy

kudrnaj@prf.cuni.cz 